\title{
PRINCIPLES OF INSECT PATHOLOGY
}




\section{PRINCIPLES OF INSECT PATHOLOGY}

by

Drion G. Boucias

and

Jacquelyn C. Pendland

University of Florida

Institute of Food and Agricultural Sciences

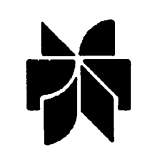

SPRINGER SCIENCE+BUSINESS MEDIA, LLC 


\section{Library of Congress Cataloging-in-Publication Data}

Boucias, D. (Drion), 1950-

Principles of insect pathology / by Drion G. Boucias and Jacquelyn

C. Pendland.

p. $\mathrm{cm}$.

Includes bibliographical references (p. ) and index.

ISBN 978-1-4613-7229-5 ISBN 978-1-4615-4915-4 (eBook)

DOI 10.1007/978-1-4615-4915-4

1. Insects--Diseases. 2. Insects--Pathogens. 3. Pathogenic

microorganisms. I. Pendland, Jacquelyn C., 1946-

II. Title.

SB942.B68 1998

632'.7--dc21

98-45713

CIP

Copyright (C) 1998 Springer Science+Business Media New York

Originally published by Kluwer Academic Publishers in 1998

Softcover reprint of the hardcover 1st edition 1998

All rights reserved. No part of this publication may be reproduced, stored in a retrieval system or transmitted in any form or by any means, mechanical, photocopying, recording, or otherwise, without the prior written permission of the publisher, Springer Science+Business Media, LCC. 


\section{TABLE OF CONTENTS}

\section{CHAPTER 1.}

\section{INSECT-PATHOGEN RELATIONSHIPS}

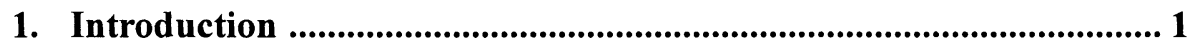

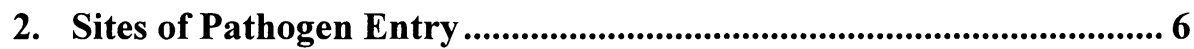

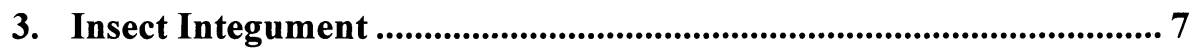

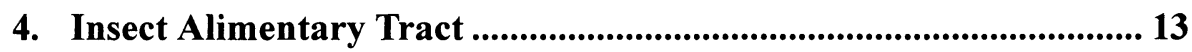

5. Spread of Pathogens in the Host Insect ............................................ 23

6. Survival and Replication of Pathogens in the Insect .......................... 24

7. Mechanisms of Cell and Tissue Damage ............................................. 26

8. Pathogen Egress and Transmission ................................................... 26

CHAPTER 2.

GENERAL FEATURES OF VIRAL DISEASE AGENTS

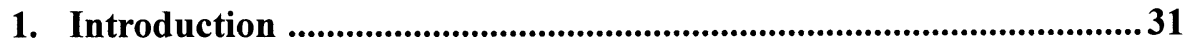

2. Morphology of Insect Viruses .................................................................34

3. Composition of Insect Viruses ..................................................................40

4. Insect Viruses as Etiological Agents of Disease......................................47

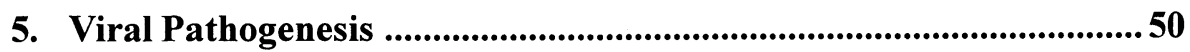


CHAPTER 3.

MAJOR GROUPS OF INSECT VIRUSES

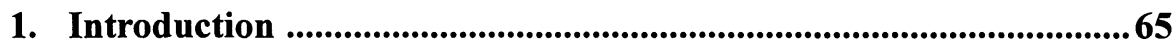

2. Group I (dsDNA viruses) ................................................................68

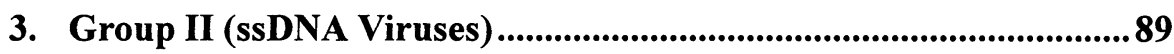

4. Group III (dsRNA Viruses) ...........................................................91

5. Group IV (+ ssRNA Viruses) ...................................................................95

6. GroupV (- ssRNA Viruses) ............................................................102

7. Group VI: Retrovirus-like Particles

(Insect Transposable Elements) ............................................................104

CHAPTER 4.

BACULOVIRUSES

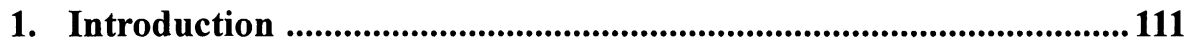

2. Structural Components of Baculoviruses........................................114

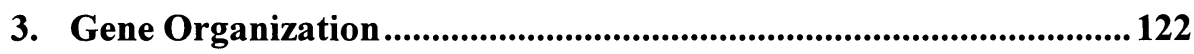

4. Baculovirus Cell Cycle ............................................................................125

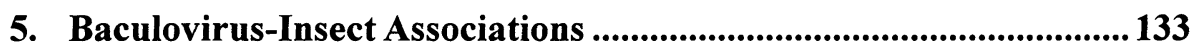

CHAPTER 5 .

CHARACTERISTICS OF THE PATHOGENIC PROKARYOTES

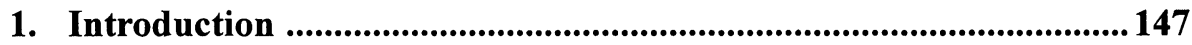

2. Bacterial Characteristics .................................................................149

3. Bacterial Growth and Metabolism .......................................................... 157

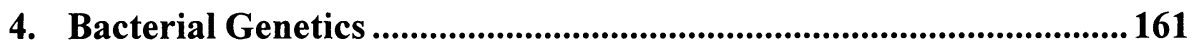

5. Detection of Bacterial Pathogens .............................................................. 167

6. Bacterial Pathogenicity …......................................................................... 170 


\section{CHAPTER 6.}

\section{INSECT PATHOGENIC BACTERIA}

1. Introduction

2. Entomopathogenic Gracilicutes

3. Entomopathogenic Firmicutes: Gram Positive, Walled Eubacteria

4. Tenericutes: The Cell Wall-less Eubacteria 209

\section{CHAPTER 7.} BACILLUS THURINGIENSIS: PRODUCER OF POTENT INSECTICIDAL TOXINS

1. Introduction

2. Isolation and Detection of Bacillus thuringiensis

3. Exoenzymes and Exotoxins of Bacillus thuringiensis 221

4. Structure and Diversity of the Delta $(\delta)$ Endotoxins 222

5. Genetics of Delta Endotoxin Synthesis 228

6. Biosynthesis of Delta Endotoxins 231

7. Mode of Action of the Delta Endotoxins 233

8. Genetic Engineering of Bacillus thuringiensis 244

CHAPTER 8. GENERAL PROPERTIES OF FUNGAL PATHOGENS

1. Introduction to the Fungal Kingdom 259

2. Fungal Characteristics 261

3. Structure and Formation of the Fungal Cell Wall .............................267

4. The Entomogenous Fungi ........................................................................2275

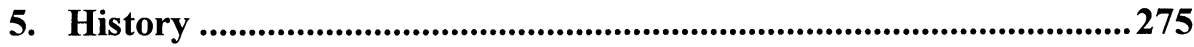

6. Fungal Disease Symptoms ......................................................................2277 
7. The Non-Pathogenic Entomogenous Fungi .....................................278

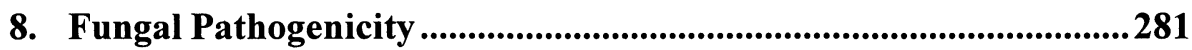

9. Pathogenicity and the Infection Pathway ........................................283

CHAPTER 9.

ENTOMOPATHOGENIC FUNGI: "PERFECT" PHYLA

1. The Entomopathogenic Water Molds and Chytrids .........................287

2. The True Fungi ..............................................................................................297

CHAPTER 10.

ENTOMOPATHOGENIC FUNGI: FUNGI IMPERFECTI

1. Hyphomycetes ................................................................................................321

2. Nomuraea rileyi: A Dimorphic Hyphomycete ...................................321

3. Beauveria bassiana: A Toxin-Producing Biocontrol Agent ...............329

4. Metarhizium anisopliae: Cuticle-Degrading Enzymes........................338

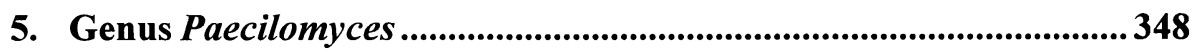

6. Verticillium lecanii: A Mycopathogen of Homopterans .....................350

7. Culicinomyces clavisporus: A Hyphomycete of Vector Mosquitos

8. Sorosporella-Syngliocladium: Alternate States of a Hyphomycete

9. Hirsutella thompsonii, Tolypocladium, and Aspergillus: Production of Secondary Metabolites

10. Coelomycetes 358

11. The Entomopathogenic Fungi: Conclusions 359

CHAPTER 11.

INSECT PATHOGENIC PROTOZOA

1. Introduction 


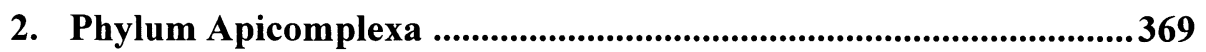

3. Phylum Ciliophora ........................................................................380

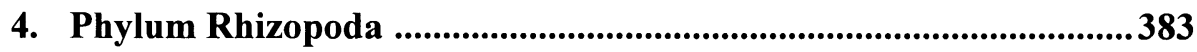

5. Phylum Zoomastigina .............................................................................387

CHAPTER 12. PHYLUM MICROSPORIDIA

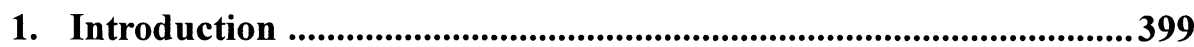

2. General Structure and Biology .........................................................402

3. The Identification and Systematics of Microsporidia .......................412

4. Representative Genera of Insect Microsporidia .................................414

CHAPTER 13.

INSECT IMMUNE DEFENSE SYSTEM, PART I: INNATE DEFENSE REACTIONS

1. Introduction 439

2. Invertebrate Members of the Ig Supergene Family ..........................441

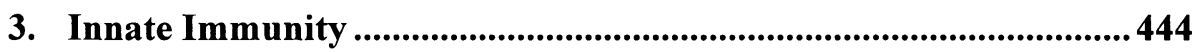

CHAPTER 14.

INSECT IMMUNE DEFENSE SYSTEM, PART II: THE RECOGNITION OF NONSELF

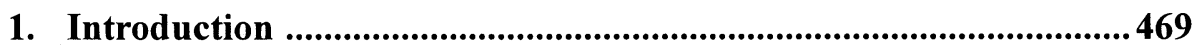

2. Phagocytic Cells ..........................................................................................469

3. The Phagocytic Process .....................................................................472

CHAPTER 15.

INSECT IMMUNE DEFENSE SYSTEM, PART III:

PROPHENOLOXIDASE CASCADE AND POST-ATTACHMENT PROCESSES OF PHAGOCYTOSIS

1. Insect Phenoloxidase 
2. Phenoloxidase-Related Specific Immune Defense Activities ...........504

3. Post-Attachment Processes of Phagocytosis .........................................517

4. Microbial Evasion of Cellular Immune Response ..............................528

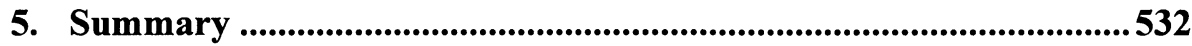




\section{PREFACE}

This book is designed to be a textbook that encompasses the general principles of insect pathology. It is divided into 15 chapters that are grouped into five sections covering the viruses, bacteria, fungi, protozoa, and host defenses. The introductory chapter for each section provides the student with a general perspective of the major taxa that contain insect pathogens. The material in these chapters highlights important biological properties of the microbes and outlines certain aspects of the pathological process. The text, ranging from general to detailed, discusses insect pathology at the cellular and molecular levels, and it emphasizes structure-function relationships. This text takes a different approach from most insect pathology books, and whenever possible, it includes discussions of homologous pathogens infecting vertebrate and plant hosts. The fact is that most determinants that regulate the pathogenicity or virulence of insect pathogens are similar, if not identical, to those found in other systems. The homology or conservation of traits among the various pathogens has allowed the insect pathologist to borrow many data from the fields of plant and animal, including human, pathology. In this book many of the concepts, subdisciplines, and terms are presented in an abbreviated format and will require further elucidation by the instructor as well as supplementary reading by the graduate student. The use of this book as a framework rather than as a definitive text is especially important in the rapidly changing areas of molecular biology, biochemistry, and evolution. We have attempted to present the student with a core of knowledge that can be used to delineate the major areas of insect pathology. We hope that this text will provide graduate students with an appreciation of the diverse biologies of the insect pathogenic microbes and that students will seek supplemental information on disease epidemiology. In addition, we believe that this text will serve as a general introductory reference 
book for both the entomologist and microbiologist interested in, as Edward Steinhaus has called it, "disease in a minor chord."

Past books on insect pathology have concentrated on the unique features of insect diseases and their potential manipulation as microbial control agents against pest insects. A separate presentation of insect pathogens as microbial control agents was omitted from this text for several reasons. Firstly, much of the critical work dealing with the development of microbial control agents was conducted in the 1970's and early 1980's, and it has been amply reviewed in numerous texts. In our experience, most entomology graduate students are wellversed in ecological concepts and have little difficulty with the concepts of biological control by insect pathogens. Secondly, many of the significant advances made in the production and formulation of insect pathogens and microbial toxins have been developed in the private sector and are proprietary. Thirdly, except for Bacillus thuringiensis, the subject of Chapter 7, very few insect pathogens have been successfully manipulated as insect control agents. In the 1980's, research papers, reviews, books, and grants optimistically presented insect pathogens as the environmentally sound alternative to chemical pesticides. But after more than two decades of private and public research, the "tremendous potential" of insect pathogens has yet to become a reality. Without question, insect diseases act as natural mortality agents and represent the third leg of the triad of biological control. As such, much of the information describing the impact of disease on insect populations is included in the biological control of insects.

The senior author acknowledges the friendship of Dr. Jean-Paul Latgé (Institut Pasteur), who over the past 15 years has served as a mentor for comparative research on mycopathogens. I would like to thank Dr. Trevor Jackson and Dr. Travis Glare for providing me the opportunity to spend most of 1997 at AgResearch in Lincoln, New Zealand. During this sabbatical I was able to work on the text of this volume and to conduct research on the amber disease in scarabs. In New Zealand I met and worked with Dr. Olivier Thaler, who kindly reviewed Chapters 5 and 6 . The authors extend their sincere appreciation to their chairman, Dr. John Capinera, who provided encouragement and allowed them to take on this project. We also acknowledge Dr. James Becnel and Elizabeth Johnson (USDA-ARS, Gainesville, Florida) for providing a short course to the senior author on the terminology and biology of the microsporidia. In addition, they and Dr. Wayne Brooks (University of North Carolina) provided critical reviews of Chapters 11 and 12 and numerous photographs and illustrations for the protozoan chapters. Complementing these figures were the contributions of Dr. T. Fukuda (USDA-ARS, Gainesville, Florida), Dr. L. Solter (University of Illinois) and Dr. D. Hall (University of Florida), who provided illustrations and micrographs of various protozoa. We acknowledge Dr. J. 
Maruniak (University of Florida) for reviewing Chapters 2 and 3 and for providing numerous figures and photographs for the virus chapters. Additional scientists, including Dr. R. Hall (University of Florida), Dr. M. Strand (University of Wisconsin), Dr. M. Obukowicz (Mycogen Corp), Dr. M. Adang (University of Georgia), Dr. T. Butt (AFRC Rothamstad), and M. Toapanta (University of Florida), provided access to photographs used in various chapters.

The authors extend their gratitude to Flora MacColl for doing the much of the typing on multiple drafts of the manuscript and for transforming it from manuscript to camera-ready form. Due to the nature of Kluwer's publishing policies Flora also undertook the task of acting as the copy editor. We are extremely grateful to Judy Boucias who spent countless hours removing the inconsistencies and errors from the text. Flora MacColl and Clare Stokes provided invaluable assistance in the labeling and construction of both the illustrations and photographic plates. Much of the artwork was done by Pat Hope, Jane Medley, and Flora MacColl (Entomology Art and Graphics). Both Flora MacColl and Pat Hope had the sometimes difficult task of converting sketches and bitmap illustrations into vector graphics. In addition, we thank James Pendland for doing freehand drawings for the immunology and fungal sections and Matthew Pendland for the computer renditions of these drawings. During the course of the writing, both Pamela Howell and Michelle Allen provided secretarial support. Finally, I would like to thank the graduate students who have taken my insect pathology class. Over the past 18 years, numerous students have provided valuable input as to what this text should include. 
Principles of Insect Pathology

This book is dedicated to Judy Boucias and to the three musketeers, Remy, Byron, and Zach, who over the past several years dealt with me through its writing, editing, and production, and to my oldest son, Jesse, who provided good excuses to visit the mountain slopes.

JCP: to Jim, Ty, and Matthew Pendland, who also had a lot to deal with during the synthesis of this text. 